BIOSFER: JURNAL PENDIDIKAN BIOLOGI (BIOSFERJPB)

2016, Volume 9 No 1, 34-39

ISSN: 0853-2451

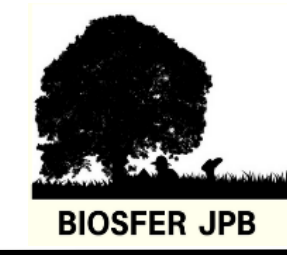

\title{
PENGARUH LEARNING START WITH A QUESTION (LSQ) TERHADAP BERPIKIR ANALISIS SISWA PADA MATERI SISTEM SARAF
}

\author{
Effect of Learning Start with a Question (LSQ) on Student's Analytical Thinking in Nervous \\ System Topic
}

\author{
Refirman D.J, Nurmasari Sartono, Sabrina Hasanah \\ Pendidikan Biologi Fakultas MIPA Universitas Negeri Jakarta \\ Email: nurmasari_sartono@yahoo.com
}

\begin{abstract}
Analytical thinking skills needed for students in solving problems encountered when learning topic are quite difficult and requires analysis of the issue. Learn to use Learning Start with a Question (LSQ) can help optimize student's analytical thinking skills. Learning Start with a Question (LSQ) involving active students to seek out and study topic that will be taught. Students learn to solve their own problems in groups and cooperate with each other. Nervous system topic requires analysis of the relationship between the constituent organ tissue structure and associate them with the mechanisms and function disorders that occur in the nervous system topic. This study aimed to determine about effect of Learning Start with a Question (LSQ) on student's analytical thinking in nervous system topic. The research was conducted in SMAN 33 Jakarta on March 2016. The reseach method used was a quasi experiment with Post Test Only Control Group Design. Subjects in this research were XI IPA 3 as experimental class and XI IPA 4 as control class. A total sample of 64 student was selected by simple random sampling technique. The instrumen used analytical thinking test was essay. Based the calculation, the average value of the test thinking analysis of the experimental class is 84 and the average value of the test thinking analysis of the control class is 82 . Based on calculation, prerequisite test analysis data obtained was not normally distributes but homogeneous. The statistical hypothesis with Mann-Whitney test result on accepted null hypothesis at $\alpha 0,05$. It showed that there was no about effect of Learning Start with a Question (LSQ) on student's analytical thinking in nervous system topic.
\end{abstract}

Keywords : Analytical thinking, LSQ, nervous system

\section{PENDAHULUAN}

Chijoke (2013) meyatakan siswa dituntut berpikir analisis dalam mencari jawaban dan fokus pada jawaban yang benar berdasarkan informasi yang ada. Berpikir analisis meningkat maka prestasi juga meningkat. Prestasi siswa Indonesia pada TIMSS (Trend Internasional Mathematics and Science Study), di tahun 2011 Indonesia menduduki peringkat 40 dari 42 negara yang berpartisipasi (Balitbang, 2011). Berkaitan dengan pernyataan diatas Jalal et al., (2009) menyatakan salah satu faktor penyebabnya siswa kurang terlatih menyelesaikan konteks yang menuntut penalaran memecahkan masalah, dan kreativitas menyelesaikannya. Menurut Eggen (2006), pembelajaran untuk pengembangan 
kemampuan berpikir analisis siswa adalah yang membuat siswa lebih dominan aktif untuk mencapai tujuan pembelajaran.

Learning Start with a Question (LSQ) merupakan pembelajaran aktif bertanya (Zaini et al., 2008). Pertanyaan yang dibuat sendiri oleh siswa memiliki kontribusi dalam pembelajaran yang bermakna karena saat mengajukan pertanyaan, siswa sedang mengkonstruk pengetahuan mereka sendiri (Chin, 2002). Salah satu materi pembelajaran yang diperlukan menganalisis adalah materi sistem saraf. Siswa menganalisis mengenai hubungan antara struktur jaringan penyusun organ dan mengaitkannya dengan mekanisme serta gangguan fungsi yang terjadi pada sistem saraf (Permendikbud RI No. 69, 2013). Berdasarkan uraian tersebut maka penulis melakukan penelitian dengan judul "Pengaruh Learning Start with a Question (LSQ) Terhadap Berpikir Analisis Siswa Pada Materi Sistem Saraf'.

\section{METODE}

Tujuan operasional dari penelitian ini adalah menganalisis pengaruh Learning Start with a Question (LSQ) terhadap berpikir analisis siswa pada materi sistem saraf. Penelitian ini dilaksanakan di SMAN 33 Jakarta semester genap tahun ajaran 2015/2016 pada bulan Maret 2016. Metode yang digunakan ialah metode kuasi eksperimen. Pengumpulan data dengan memberikan Posttest. Data juga dapat diperoleh dari observasi keterlaksanaan pembelajaran, wawancara guru dan siswa. Penelitian ini menggunakan desain penelitian Post Test Only Control Group Design.

Populasi target adalah siswa SMAN 33 Jakarta tahun 2015/2016. Populasi terjangkau adalah siswa kelas XI Matematika dan Ilmu Alam (MIA). Sampel yang didapatkan dari populasi terjangkau yaitu XI MIA 3 dan XI MIA 4. Masing-masing kelas kontrol dan eksperimen terdiri dari 32 siswa. Untuk menguji validitas butir soal menggunakan rumus Pearson Product Moment, Untuk menguji reliabilitas butir soal menggunakan rumus Alpha Cronbach (Arikunto, 2010).

\section{HASIL DAN PEMBAHASAN}

Hasil penelitian dapat digabung dengan pembahasan menjadi bab Hasil dan Pembahasan. Pemisahan atau penggabungan kedua bagian ini bergantung pada keadaan data dan kedalaman pembahasannya sesuai dengan arahan pembimbing. Bila Hasil dan Pembahasan disatukan dalam satu bab, sajikan dahulu hasil penelitian, beri penjelasan yang cukup untuk temuan penting, lanjutkan dengan analisis dan kemudian dengan pembahasan. Subbab dalam Hasil dan Pembahasan dikembangkan secara sistematis dan mengarah ke simpulan.

\section{Hasil}

Rata-rata nilai tes berpikir analisis siswa pada kelas eksperimen sebesar 83,53 sedangkan pada kelas kontrol sebesar 81,75. Perbandingan rata-rata nilai tes berpikir analisis siswa dapat dilihat pada gambar 1. LAULINTAS 


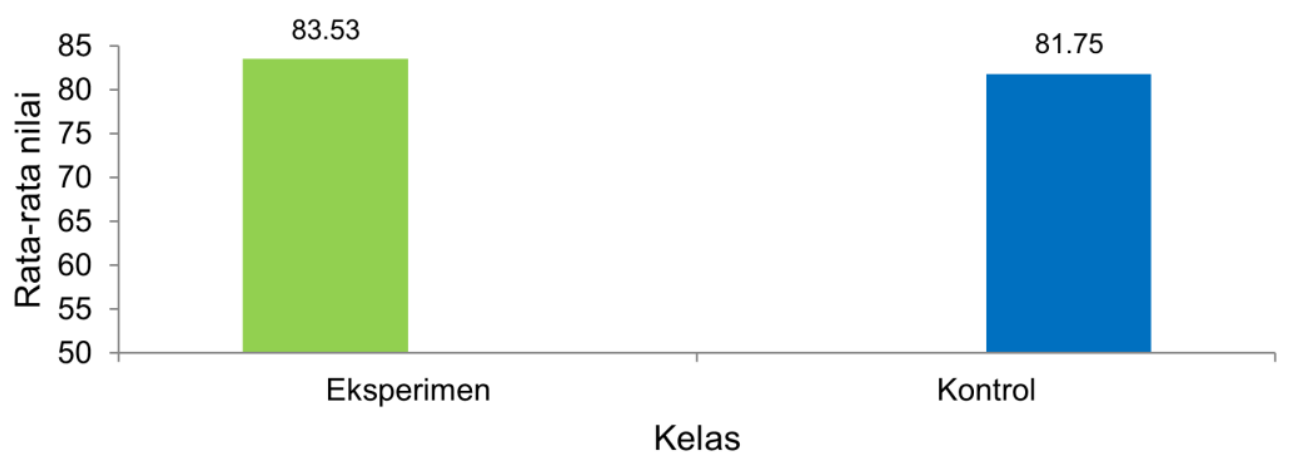

Gambar 1. Perbandingan rata-rata tes berpikir analisis siswa

Tabel 1 Uji hipotesis

Berdasarkan hasil pengujian diperoleh nilai signifikansi > 0,05 maka terima $\mathrm{H}_{\mathrm{o}}$, artinya

Test Statistics ${ }^{\mathrm{a}}$

\begin{tabular}{|c|c|}
\hline & kemampuan analisis \\
\hline Mann-Whitney U & 509.000 \\
\hline $\mathrm{Z}$ & -.041 \\
\hline $\begin{array}{l}\begin{array}{l}\text { Asymp. } \\
\text { tailed })\end{array} \\
\text { Sig. }\end{array}$ & .967 \\
\hline
\end{tabular}

a. Grouping Variable: Kelas

tidak terdapat pengaruh Learning Start with a Question (LSQ) terhadap berpikir analisis siswa pada materi sistem saraf.

\section{Pembahasan}

Peneliti mengelompokkan beberapa faktor yang menjadi penyebab selisih rata-rata nilai tes berpikir analisis siswa kelas eksperimen dan kelas kontrol relatif kecil. Faktor pertama adalah siswa belum terbiasa belajar mandiri di awal pembelajaran. Hal ini didukung dengan wawancara guru yang mengatakan bahwa dalam pembelajaran sehari-hari di kelas, guru yang biasanya menjelaskan materi dengan bantuan slide power point sedangkan siswa mendengarkan dan mencatat. Berdasarkan hasil observasi, siswa menunjukkan sikap reseptif karena terbiasa menerima pengetahuan dan mendapat pertanyaan langsung dari guru. Hal ini sesuai dengan pendapat Silberman (2006) yang menyatakan bahwa proses mempelajari hal baru tidak efektif jika siswa bersifat reseptif. Penerapan pembelajaran LSQ memberikan pengaruh terhadap berpikir analisis siswa namun hasilnya masih kurang maksimal. Lain halnya dengan pembelajaran STAD, secara umum pola pembelajaran tersebut sudah sering digunakan dalam pembelajaran sehari-hari di kelas. Sebagaimana hasil penelitian yang dilakukan oleh Ramadhani (2013) bahwa pembelajaran yang belum biasa digunakan, menjadi tidak efektif dibandingkan pembelajaran yang sudah biasa digunakan. 
Faktor kedua adanya tingkat kecerdasan yang berbeda-beda yang menyebabkan perbedaan dalam kemampuan bertanya dan berpikir analisis. Dari hasil observasi, siswa yang menguasai bahan bacaan akan mengajukan pertanyaan yang lebih mendalam. Siswa yang aktif bertanya juga sebagian adalah siswa yang pandai, akibatnya siswa yang pandai dengan antusias tinggi dapat mengembangkan potensinya secara optimal. Dari hasil wawancara dengan guru diketahui bahwa siswa yang dominan bertanya adalah siswa yang sama. Susatyo, et al., (2009) dan Mediawati (2014) dalam penelitiannya menemukan bahwa tidak semua siswa akan mengajukan pertanyaan dan mengalami perkembangan karena tidak semua konsep yang dikontruksi setiap siswa semuanya sama dan hal ini disebabkan karena tingkat kecerdasan yang berbeda-beda. Hal ini sebagaimana teori yang menyatakan bahwa hambatan dalam menangkap materi menggunakan pembelajaran LSQ adalah kecerdasan yang berbeda-beda saat pelaksanaan pembelajaran dengan LSQ (Zaini et al., 2008). Adi (2015) menyatakan bahwa salah satu faktor yang mempengaruhi keberhasilan proses pembelajaran adalah tingkat kecerdasan. Akan tetapi peneliti tidak meneliti tingkat kecerdasan siswa dan ini merupakan keterbatasan penelitian.

Faktor ketiga adalah siswa kurang terstimulasi untuk bertanya, tidak menyimak tujuan pembelajaran, dan tidak termotivasi dalam belajar sehingga memiliki pengetahuan yang tidak sesuai. Sebagaimana diungkapkan oleh guru bahwa terkadang siswa kurang termotivasi untuk membaca dan menulis, lebih mendengar. Dari hasil observasi, ada beberapa siswa tidak membaca, tidak menandai atau tidak mencatat hal-hal yang tidak dimengerti dari bahan bacaan yang ditugaskan guru. Sebagaimana salah satu kelemahan dari LSQ menurut Zaini et al., (2008), Siswa yang minat membacanya rendah akan susah mengikuti akan sulit mengikuti pelajaran karena awal pelajaran dimulai dengan membaca. Namun keinginan siswa untuk membaca tergantung dari motivasi siswa tersebut. Sesuai dengan hasil penelitian Karwadi (2004), bahwa semakin besar motivasi belajar siswa, semakin besar pula kemungkinan tercapainya tujuan pembelajaran. Sayangnya peneliti tidak meneliti tingkat motivasi siswa dan ini merupakan keterbatasan penelitian. Selain itu, LSQ juga mempunyai kelemahan, yaitu tidak menjamin bahwa semua siswa belajar dengan tekun, penuh aktivitas dan terarah (Susatyo, et al., 2009).

Faktor keempat adalah siswa terlihat malu-malu dan masih sulit untuk menyampaikan pertanyaan. Hal ini sesuai dengan yang diungkapkan siswa, mereka akan diam saja karena cemas dan takut bertanya, ada pula yang bertanya jika ditunjuk guru dan mereka lebih senang bertanya kepada teman daripada guru. Sebagaimana diungkapkan oleh guru bahwa siswa tidak aktif bertanya di kelas karena siswa tersebut takut atau malu bertanya, yang bertanya pun memang lebih dominan siswa yang sama. Persentase siswa yang bertanya pada kelas eksperimen sebesar $62 \%$ dan $67 \%$ pada kelas kontrol. Hal ini sesuai dengan salah satu kelemahan LSQ yaitu tidak semua siswa berani mengajukan pertanyaan (Zaini, et al., 2008). Siswa yang aktif bertanya adalah siswa yang memilki rasa percaya diri yang tinggi, mereka tidak malu untuk bertanya mengenai konsep materi yang dianggap sulit tetapi untuk siswa yang memiliki kepercayaan diri yang rendah sulit untuk bertanya mengenai konsep materi yang dirasa kurang memahami (Susatyo, et al., 2009). Padahal jika siswa mengikuti pembelajaran di kelas tanpa rasa ingin tahu dan tanpa mengajukan pertanyaan, kegiatan belajar tersebut bersifat pasif (Halim, et al., 2013).

Faktor kelima adalah kurangnya keterampilan siswa dalam mengajukan pertanyaan. Berdasarkan hasil observasi, ada beberapa siswa kesulitan dalam menyusun 
suatu pertanyaan. Masih ada beberapa siswa jenis pertanyaan belum mencapai aspek analisis. Guru mengungkapkan bahwa perlu memilah jenis pertanyaan, karena terdapat sejumlah siswa dengan pertanyan yang hampir sama. Sardiman (2006) menyatakan bahwa pertanyaan dalam pembelajaran adalah penting karena dapat menjadi perangsang yang mendorong siswa mengembangkan kemampuan berpikir. Oleh karena itu, dalam tahapan pembelajaran guru seharusnya menjadi fasilitator dan menstimulasi siswa aktif bertanya sehingga membantu mengoptimalkan kemampuan berpikir (Susatyo, et al., 2009). Peranan guru sangatlah penting guna mengarahkan siswa agar berpikir analisis dalam proses pembelajaran. Guru harus memilih dan menerapkan pembelajaran yang inovatif dan mampu mengaktifkan belajar siswa (Solikhah, et al., 2012).

Faktor keenam adalah pembelajaran kelas eksperimen dan kontrol memiliki beberapa persamaan dalam langkah-langkah pembelajaran, seperti guru mengelompokkan siswa untuk menjadi beberapa kelompok diskusi. Hal ini sesuai dengan langkah kegiatan pembelajaran di RPP. Hasil wawancara non struktur setelah penelitian, dikatakan guru bahwa siswa menjadi lebih aktif dengan kedua pembelajaran tersebut. Sedangkan dari hasil wawancara dengan siswa, diketahui mereka lebih senang bertanya kepada teman daripada guru, sehingga belajar berkelompok menjadi sangat bermanfaat dalam peningkatan hasil pembelajaran. Sesuai dengan pendapat Brown dalam Isjoni (2010) bahwa pembelajaran berkelompok dalam tim melatih siswa untuk memiliki keterampilan berpikir melalui penyelesaian masalah. Begitu pula hasil penelitian Syafrina (2012) bahwa pemahaman siswa terhadap materi akan lebih mendalam ketika proses pembelajaran memungkinkan terjadinya diskusi baik dengan sesama siswa maupun antara siswa dengan guru. LSQ dan STAD adalah dua pembelajaran yang berbeda yang memiliki kelebihan masing masing. Namun, keduanya sama-sama memiliki tahapan dalam pembelajaran kelompok dan memberikan dampak positif terhadap peningkatan hasil belajar.

\section{KESIMPULAN}

Selisih rata-rata nilai berpikir analisis siswa kelas eksperimen dan kelas kontrol relatif kecil. Berdasarkan pengujian hipotesis dapat disimpulkan bahwa tidak terdapat pengaruh Learning Start with a Question (LSQ) terhadap berpikir analisis siswa pada materi sistem saraf.

\section{DAFTAR PUSTAKA}

Adi, Ari. (2015). Pengaruh Pembelajaran Kooperatif Student Team Achievement Divisions (STAD) Disertai LKS Terhadap Hasil Belajar Biologi Siswa Kelas VII SMP Negeri 21 Surakarta. Jurnal Pendidikan Biologi, 4 (2), 20-24.

Arikunto, Suharismi. (2010). Prosedur Penelititan Suatu Pendekatan Praktik. Jakarta: Rineka Cipta.

Balitbang. (2011). Hasil Survei TIMSS: 2011. Trends Internasional Mathematics and Scince Study. US: TIMSS and PIRLS International Study Center

Chijoke. (2013). Determination of the analytical skill level of secondary school chemistry students in Imo state of Nigeria. Journal of Education and General Studies, 2(10), 336-353. Chin, C. (2002). Student-Generated Questions: Encouraging Inquisitive Minds in Learning Science. Journal of Teaching and Learning, 23(1), 59-67. 
Eggen P.,D., Kauchak D.,P. (2006). Strategies and Models for Teachers Teaching Content and Thinking Skills, 5th edition. USA: Pearson Education Inc.

Halim, et al. (2013). Model Pembelajaran Cooperative dengan Pendekatan Active Learning pada Materi Aljabar, Jurnal Pendidikan Matematika STKIP PGRI Sidoarjo, 1 (1), 83-96.

Isjoni. (2010). Cooperative Learning efektivitas pembelajaran berkelompok. Bandung: Alfabeta.

Jalal, Fasli, et al. (2009). Teacher Sertification in Indonesia: A strategy For Teacher Quality Improvement. Jakarta: Jurnal Departemen Pendidikan Nasional RI.

Karwadi. (2004). Upaya Guru Dalam Menumbuhkan Motivasi Belajar Siswa Di Sekolah. Jurnal Pendidikan Agama Islam, 1 (1), 41-52.

Mediawati, Dina. (2014). Perbedaan antara penerapan pembelajaran Learning Start with a Question (LSQ) dengan Question Student Have (QSH) pada penguasaan konsep siswa mengenai ekosistem. Jakarta: Fakultas Matematika dan Ilmu Pengetahuan Alam UNJ.

Permendikbud. (2013). Kerangka Dasar Dan Struktur Kurikulum Sekolah Menengah Atas/Madrasah Aliyah. Jakarta: Kementerian Pendidikan Dan Kebudayaan RI.

Ramadhani, Witri. (2013). Pengaruh Model Pembelajaran Question Student Have dan STAD terhadap Hasil belajar Sistem Endokrin di SMAN 67 Jakarta. Jakarta: Fakultas Matematika dan Ilmu Pengetahuan Alam UNJ.

Sardiman. (2006). Interaksi dan Motivasi Belajar Mengajar. Jakarta: Raja Grafindo Persada.

Silberman, Melvin L. (2006). Active Learning: 101 Strategi Pembelajaran Aktif. Jakarta: Nusamedia.

Solikhah, et al. (2012). Penerapan Strategi LSQ Berbantuan Media Audio Visual untuk Meningkatkan Hasil Belajar Ekonomi. Economic Education Analysis Journal, 1 (2), 1-8.

Susatyo, Eko, Sri Martini Rahayu, Restu Yuliawati. (2009). Penggunaan Model Learning Start With A Question Dan Self Regulated Learning Pada Pembelajaran Kimia. Jurnal Inovasi Pendidikan Kimia, 3 (1), 406-412.

Syafrina, Mia. (2012). Implementasi strategi Learning Start with a Question dalam Meningkatkan kemampuan komunikasi matematis Siswa SMAN 1 Padang. Jurnal Pendidikan Matematika, 1 (1), 29-34.

Zaini, Hisyam., Munthe, Bermawy., dan Aryani, Sekar Ayu. (2008). Strategi Pembelajaran Aktif. Yogyakarta: Pustaka Insan Madani. 